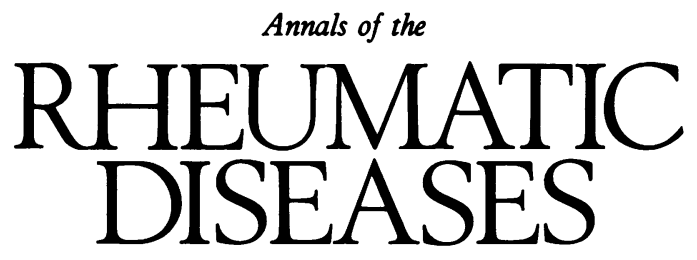

Leader

\title{
Does aluminium have a pathogenic role in dialysis associated arthropathy?
}

Dialysis has improved the prognosis and quality of life for patients with chronic renal insufficiency, but at the price of various complications. The first to be recognised were the acute myoclonic encephalopathies, ${ }^{12}$ whose main cause is aluminium overload. This overload results from the use of phosphate binding gels containing aluminium to lower the hyperphosphataemia of these patients, and also from dialysis solutions with a high aluminium content. The incidence of this syndrome has decreased dramatically since the lowering of aluminium concentrations in dialysis solutions and the monitoring of plasma aluminium concentrations in these patients. Nevertheless, some patients still have altered cerebral function related to moderate aluminium overload. ${ }^{3}$ Other complications can arise in patients receiving long term dialysis, ${ }^{45}$ including hypochromic anaemia ${ }^{6}$ and osteomalacia. ${ }^{7}$ The common factor in these complications is the toxicity of aluminium to the organs and tissues affected.

Thus aluminium can induce encephalopathies in rats, ${ }^{8}$ and its tropism for the grey matter of the central nervous system in man has been shown. ${ }^{1}$ Similarly, this element can inhibit bone mineralisation'; it is toxic to osteoblasts and accumulates at the mineralisation front of bone in patients undergoing dialysis. ${ }^{59}$ Indirect evidence of the toxicity of aluminium is the improvement in neurological, haematological, and bony disorders produced by the chelator desferrioxamine. In particular this chelator enhances the activity of erythrocyte (and probably brain) dihydropteridine reductase, and improves the psychomotor function of the patient receiving long term haemodialysis. ${ }^{3}$

\section{Dialysis associated arthropathy}

Certain osteoarticular complications of long term haemodialysis were recognised early. ${ }^{10-12}$ These include epiphysial necrosis, septic or microcrystalline arthritis, lesions of hyperparathyroidism, and tendon ruptures. The increased survival times of patients undergoing haemodialysis have more recently shown a set of manifestations ${ }^{13-18}$ described under the term 'dialysis associated arthropathy'. This crippling disorder affects a large number of patients after 10 years of haemodialysis. It is expressed clinically by carpal tunnel syndrome, often bilateral and recurrent, or destructive arthropathies affecting the spine and limbs. Radiographs typically show erosive spondyloarthropathy and juxta- articular cystic lesions of the limbs, predominantly in the wrists, shoulders, knees, and hips. The histological aspects are highly polymorphous, varying with the joint and the patient, so that division of dialysis associated arthropathy into several subgroups has been suggested. ${ }^{17}$ Nevertheless, a particular amyloidosis consisting of $\beta_{2}$ microglobulin amyloid $^{1920}$ is often involved in compression of the median nerve and forms the main constituent of 'bone cysts'. $\beta_{2}$ Microglobulin deposits undoubtedly participate in the lesions of dialysis associated arthropathy, but such deposits are sometimes asymptomatic ${ }^{16} 1721$ and do not account for all the joint lesions. Other histological findings have been reported, ${ }^{172223}$ including non-specific synovitis, especially in arthropathies with hydarthrosis; synovial fibrosis; and iron deposits in the synovium.

Several factors, none of them clearly dominant, seem to contribute to the appearance of dialysis associated arthropathy. The duration of dialysis plays a part, but at equal durations of dialysis the incidence of arthropathy increases with the patient's age. ${ }^{24}$ Hyperparathyroidism may favour the destructive spondyloarthropathies, ${ }^{17}$ whereas it does not seem to be a risk factor in carpal tunnel syndrome. ${ }^{18}$ Other factors have been considered, such as the type of dialysis membrane, ${ }^{25}$ or the presence within affected joints of microcrystals $s^{26}$ or of deposits of iron ${ }^{17222327}$ or aluminium. ${ }^{28-30}$ As aluminium is toxic to various tissues, particularly nervous and bony tissues, a discussion of its role in the pathogenesis of dialysis associated arthropathy may be useful.

\section{Articular accumulation of aluminium in dialysis associated arthropathy}

It has been established that aluminium accumulates in the articular structures of patients receiving long term dialysis. In 1981 and 1984 we reported increased deposition of aluminium in the joint structures in haemodialysis patients receiving phosphate binding agents containing aluminium. ${ }^{28}{ }^{29}$ Aluminium crosses the synovial barriers; it is found in synovial fluid, and the aluminium concentrations in synovial tissue are two- to 10-fold higher in dialysis patients ingesting gels containing aluminium than in patients with normal renal function. ${ }^{29}$ More recently, we compared the concentrations of aluminium in synovial tissue and joint cartilage samples from 28 patients who had been receiving 
dialysis for an average of 123 months with those from controls of the same age who had not been given drugs containing aluminium, ${ }^{30}$ all of whom were operated on for carpal tunnel syndrome or arthropathy of the limbs. We found that aluminium concentrations were about 10-fold higher in the haemodialysed patients than in controls. In patients receiving dialysis the concentrations were $17 \cdot 4 \mu \mathrm{g} / \mathrm{g}$ wet weight in synovial tissue and $20.2 \mu \mathrm{g} / \mathrm{g}$ in cartilage; the respective values in control patients were 1.7 and $2.4 \mu \mathrm{g} / \mathrm{g}$. Yver confirmed these data using the desferrioxamine test to evaluate the accumulation of aluminium in 63 patients who had undergone haemodialysis for at least six years. ${ }^{31}$ The aluminium overload was greater in the patients with dialysis associated arthropathy than in those free of the condition. In a recent multicentre study (Kessler $e t$ al, unpublished data), although the desferrioxamine test certainly did not show a statistically significant difference in aluminium overload between these two types of dialysis patients, nevertheless the highest aluminium increments were found in the patients with joint complications.

\section{Is aluminium toxic to joint tissues?}

Though aluminium overload has not been shown to cause joint disorders, it has been implicated by various studies, some of them concerning the mechanism of this toxicity. Aluminium may favour damage to joints, and particularly to cartilage, by permitting the release of free radicals. Mitrovic compared the action of various metallic salts on the production of oxygen free radicals by neutrophilic leucocytes in vitro. ${ }^{32}$ At concentrations from $0.5 \times 10^{-3} \mathrm{~mol} / 1$ to $1 \times 10^{-6} \mathrm{~mol} / \mathrm{l}$, only three of them $\left(\mathrm{AlCl}_{3}, \mathrm{Al}_{2}\left(\mathrm{SO}_{4}\right)_{3}\right.$, and $\mathrm{FeCl}_{3}$ ) stimulated the production of oxygen free radicals. As the two aluminium salts stimulated three times the production that $\mathrm{FeCl}_{3}$ stimulated it might be suggested that aluminium when concentrated in the joint tissues increases the production of oxygen free radicals, resulting in lysis of chondrocytes and depolymerisation of the macromolecules of the cartilage matrix.

Studies in animals have shown the inflammatory effect of aluminium. When injected in the rat rear paw, crystalline aluminium phosphate causes a local inflammation, which is less severe than that caused by carrageenan but more severe than that caused by calcium hydrogen phosphate dihydrate. ${ }^{33}$ The administration of amorphous or crystalline aluminium phosphate into rabbits' knees induces synovitismore marked with the crystalline form-associated with joint effusion. ${ }^{34}$ This resembles the synovitis with hydarthrosis seen in patients with dialysis associated arthropathy. The histology ${ }^{34}$ of these experimentally induced arthropathies showed acute synovitis with partial ulceration of the synovial lining, which was replaced by fibrinleucocyte aggregates. The cartilaginous lesions, visible in transmission electron microscopy, were moderate: a slight lipid excess in chondrocytes with sometimes a localised increase in microfilaments and, particularly, faster cell multiplication than in controls, and the presence of mineralisation vesicles. In scanning electron microscopy, coupled with wavelength dispersive microprobe, aluminium associated with phosphate was found in cellular elements. In addition, transmission electron microscopy showed lysosomal inclusions of phagocytosed material in synovial cells. These features resemble those seen previously in a patient with chronic renal insufficiency receiving haemodialysis and treated with aluminium compounds. ${ }^{28} 29$ Similar lesions were seen in cerebral tissue of patients with aluminium intoxication, where the lysosomes contained aluminium associated with phosphate. ${ }^{35}$ As in cerebral cells, the presence of intracellular aluminium in the synovial cells shows that lysosomes are sites of concentration and precipitation of mineral elements.
Aluminium may also have an indirect effect. It is mainly bound to transferrin in plasma ${ }^{36-38}$; hence the possibility of interactions with iron. Thus joint deposits of iron have been shown in joint tissues containing $\beta_{2}$ microglobulin in patients undergoing dialysis. ${ }^{39}$ These iron deposits favour inflammatory infiltrates. ${ }^{17} \mathrm{~A}$ synergy between iron and aluminum in the tissues has been suggested. Al(III) salts did not stimulate peroxidation of ox brain phospholipid liposomes, but greatly accelerated the peroxidation induced by iron(II) salts at acidic $\mathrm{pH}$ values. ${ }^{40}$

\section{Possible interaction between aluminium and $\beta_{2}$ microglobulin}

The accumulation of aluminium might be simply a thesaurismosis favoured by aging, tissue destruction, or amyloid deposits. As the highest concentrations of aluminium in synovial tissue are seen in the presence of $\beta_{2}$ microglobulin deposits $^{30}$ it is possible that this amyloid favours the accumulation of aluminium. The affinity of isotopic tracers for the various forms of amyloid strengthens that hypothesis. Grateau et al showed the presence of increased articular or periarticular uptake with technetium-99 methylene diphosphonate in six of seven patients presenting a dialysis associated arthropathy with amyloidosis. ${ }^{41}$ In these seven patients, moreover, there was an aluminium overload, as indicated by a positive desferrioxamine test.

It is also possible that the presence of aluminium favours the accumulation of $\beta_{2}$ microglobulin, ${ }^{18} 2042$ or at least that there is a synergy ${ }^{18}$ between aluminium and the $\beta_{2}$ microglobulin fragments which causes amyloid deposits to form joint and bony abnormalities. Urena et al determined the distribution of exogenous $\beta_{2}$ microglobulin after intravenous injection of ${ }^{125}$ I labelled $\beta_{2}$ microglobulin into bilaterally nephrectomised rats. ${ }^{43}$ In rats previously intoxicated with aluminium the activity of ${ }^{125}$ I labelled $\beta_{2}$ microglobulin was higher in the spleen, which is also the site of preferential aluminium accumulation. ${ }^{44} \mathrm{~A}$ parallelism with Alzheimer's disease seems to strengthen this theory. In this disorder, in which the genetic background surely plays a part, there is biological, ${ }^{45-47}$ epidemiological, ${ }^{48}$ and experimental ${ }^{49}$ evidence of the participation of aluminium. At the centre of senile plaque cores in Alzheimer's disease the amyloid $\mathrm{A}_{4}$ protein is associated with amorphous deposits of aluminosilicates. ${ }^{475051}$ These might favour the formation locally of amyloid $\mathrm{A}_{4}$ protein. ${ }^{47} 5051$ This hypothesis is reinforced by the demonstration of deposits of amyloid $\mathrm{A}_{4}$ protein in the brains of patients receiving dialysis, who have slightly raised blood and cerebral concentrations of aluminium and silicon. ${ }^{51}$ As age plays an essential part both in dialysis associated arthropathy ${ }^{24}$ and Alzheimer's disease, ${ }^{52}$ these two disorders would seem to be degenerative diseases arising in a particular context (genetic for one, chronic dialysis for the other), and to be favoured by exogenous factors, including aluminium.

For a better definition of the pathogenic role of each of the factors participating in dialysis associated arthropathy it would be appropriate to classify patients with the disorder into more homogeneous subgroups. Experimental, clinical, and epidemiological studies might help to define the role of each factor, but only longitudinal studies of present dialysis patients whose aluminium supply is limited will make it possible to confirm or rule out the articular toxicity of aluminium.

URA CNRS 1288 PATRICK NETTER Physiopathologie et Pharmacologie Articulaires, MICHELE KESSLER Faculté de Médecine, BP 184, 54505 Vandoeuvre Les Nancy Cedex, ALAIN GAUCHER France 
1 Alfrey A C, Legendre G R, Kaehny W D. The dialysis encephalopathy syndrome. Possible aluminium intoxication. N Engl 7 Med 1976; 294: 184-8.

2 Garrett P J, Mulcahy D, Carmody M, O'Dwyer F W. Aluminium encephalopathy: clinical and immunological features. $Q \mathcal{F}$ Med 1988; 258: $775-83$.

3 Altmann P, Dhanesha U, Hamon C, Cunningham J, Blair J, Marsh F. Disturbance of cerebral function by aluminium in haemodialysis patients without overt aluminium toxicity. Lancet 1989; ii: 7-11.

4 Llach F. Aluminium in renal disease. 7 Am Coll Nutr 1989; 8: 292-5.

5 Lione A. Aluminium toxicology and the aluminium-containing medications. Pharmacol Ther 1985; 29: 255-85.

6 Altmann P, Plowman D, Marsh F, Cunningham J. Aluminium chelation therapy in dialysis patients: evidence for inhibition of haemoglobin synthesis by low levels of aluminium. Lancet 1988; i: 1012-5.

7 Parkinson I S, Ward M K, Kerr D N S. Dialysis encephalopathy, bone disease and anaemia. The aluminium intoxication syndrome during regular haemodialysis. F Clin Pathol 1981; 84: 1285-94.

8 Berlyne G M, Yagil R, Ben-Ari J, Weinberger G, Knopf E, Danovitch G M. Aluminium toxicity in rats. Lancet 1972; i: 564-8.

9 Dunstan C R, Evans R A, Hills E, Wong S Y, Alfrey A C. Effect of aluminium and parathyroid hormone on osteoblasts and bone mineralization in chronic renal failure. Calcif Tissue Int 1984; 36: 133-8.

10 Brown E A, Arnold I R, Gower P E. Dialysis arthropathy: complication of long-term treatment with hemodialysis. Br Med F 1986; 292: 163-6.

11 Goldstein S, Winston E, Chung T J, Chopra S, Pariser K. Chronic arthropathy in long term hemodialysis. Am $\mathcal{J}$ Med 1985; 78: 82-6.

12 Rubin L A, Fam A G, Rubenstein J, Campbell J, Saiphoo C. Erosive azotemic osteoarthropathy. Arthritis Rheum 1984; 27: 1086-94.

13 Muñoz-Gómez J, Bergadá-Barado E, Gómez-Pérez R, et al. Amyloid arthropathy in patients undergoing periodical haemodialysis for chronic renal failure: a new complication. Ann Rheum Dis 1985; 44: 729-33.

14 McClure J, Bartley C J, Ackrill P. Carpal tunnel syndrome caused by amyloid containing $\beta_{2}$ microglobulin: a new amyloid and a complication of long term

15 Bardin T, Kuntz D. The arthropathy of chronic hemodialysis. Clin Exp Rheumatol 1987; 5: 379-86.

16 Bardin T, Zingraff J, Shirahama T, et al. Hemodialysis-associated amyloidosis and beta-2 microglobulin; clinical and immunohistochemical study. $A m \mathcal{J}$ Med 1987; 83: 419-24.

17 Hurst N P, van den Berg R, Disney A, et al. 'Dialysis related arthropathy': a survey of 95 patients receiving chronic haemodialysis with special reference
to $\beta_{2}$ microglobulin related amyloidosis. Ann Rheum Dis 1989; 48: 409-20.

18 Kleinman K S, Coburn J W. Amyloid syndromes associated with hemodialysis. Kidney Int 1989; 35: 567-75.

19 Gejyo F, Yamada T, Odani S, et al. A new form of amyloid protein associated with chronic hemodialysis was identified as $\beta_{2}$ microglobulin. Biochem Biophys Res Commun 1985; 129: 701-6.

20 Gorevic P D, Munoz P C, Casey T T, et al. Polymerization of intact $\beta_{2}$ microglobulin in tissue causes amyloidosis in patients on chronic hemodialysis. Proc Natl Acad Sci USA 1986; 83: 7908-12.

21 Zingraff J, Drüeke T, Bardin T. Dialysis-related amyloidosis in the sternoclavicular joint. Nephron 1989; 52: 367

22 Hardouin P, Lecomte-Houcke M, Flipo R M, et al. Current aspects of osteoarticular pathology in patients undergoing hemodialysis: study of 80 patients. Part 2 . Laboratory and pathologic analysis discussion of the pathogenetic mechanism. $\mathcal{F}$ Rheumatol $1987 ; 14: 784-7$.

23 Foissac-Gegoux P, Flipo R M, Hardouin P, et al. Aspects actuels de la pathologie ostéoarticulaire des hémodialysés. Nephrologie 1986; 4: 157-63. Gaucher A, Kessler M, Netter P, Azoulay E, Péré P, Mur J M. Dialysis arthropathy: the effect of age: $\mathcal{F}$ Rheumatol 1988; 15: 1880-1.

25 Vandenbroucke J M, Jadoul M, Maldague B, Huaux J P, Noel H, Van Ypersele de Strihou C. Possible role of dialysis membrane characteristics in amyloid osteoarthropathy. Lancet 1986; i: 1210-1.

26 Kuntz D, Naveau B, Bardin T, Drueke T, Treves R, Dryll A. Destructive spondylarthropathy in hemodialyzed patients. Arthritis Rheum 1984; 27: 369-75.
27 Cary N R B, Sethi D, Brown E A, Erhardt C C, Woodrow D F, Gower P E. Dialysis arthropathy: Amyloid or iron? Br Med f 1986; 293: 1392-4.

28 Netter P, Burnel D, Hutin M F, Kessler M, Faure G. Aluminium in joint tissues of patient taking aluminium hydroxide. Lancet 1981; i: 1056-7.

29 Netter P, Kessler M, Burnel D, et al. Aluminium in the joint tissues of chronic renal failure patients treated with regular hemodialysis and aluminium compounds. I Rheumatol 1984; 11 : 66-70.

30 Netter P, Kessler M, Gaucher A, et al. Aluminium and dialysis arthropathy. Lancet 1988; i: 886-7.

31 Yver L, Blanchier D, Buiquang D, Cabanne J F, Charmes J P, Meftahi H. Does aluminium induce dialysis amyloidosis? Nephrology Dialysis Transplantation 1987; 2: 450-1.

32 Mitrovic D R, Stankovic A, Front P, Kuntz D. La toxicité de l'aluminium sur les tissus est-elle due à la production de radicaux libres d'oxygène? Presse Med 1987; 16: 1702 .

33 Royer R J, Delongeas J L, Netter P, et al. Inflammatory effect of aluminium phosphate on rat paws. Pathol Biol (Paris) 1982; 30: 211-5.

34 Delongeas J L, Netter P, Boz P, Faure G, Royer R J, Gaucher A. Experimental synovitis induced by aluminium phosphate in rabbits. Biomed Pharmacother 1984; 38: 44-8.

35 Galle P, Chatel M, Berry J P, Menault F. Encéphalopathie myoclonique progressive des dialysés: présence d'aluminium en forte concentration dans les lysosomes des cellules cérébrales. La Nouvelle Presse Medicale 1979; 8: $4091-4$.

36 Martin R B, Savory J, Brown S, Bertholf R L, Wills M R. Transferrin binding of $\mathrm{Al}^{3+}$ and $\mathrm{Fe}^{3+}$. Clin Chem 1987; 33: 405-7

37 Martin R B. The chemistry of aluminium as related to biology and medicine. Clin Chem 1986; 32: 1797-806.

38 Cochran $M$, Coates $J$, Neoh $S$. The competitive equilibrium between aluminium and ferric ions for the binding sites of transferrin. FEBS Lett 1984; 176: 129-32.

39 Kessler M, Netter P, Grignon B, et al. Destructive $\beta 2$ microglobulin amyloid arthropathy of the cervico-occipital hinge in a hemodialyzed patient. Arthritis Rheum 1990; 33: 602-4.

40 Gutteridge J M C, Quinlan G J, Clark I, Halliwell B. Aluminium salts accelerate peroxidation of membrane lipids stimulated by iron salts. Biochim Biophys Acta 1985; 835: 441-7.

41 Grateau G, Zingraff J, Fauchet $M$, et al. Radionuclide exploration of dialysis amyloidosis: preliminary experience. Am $\mathcal{F}$ Kidney Dis 1988; 11: 231-7.

42 Grunfeld J P. Quelques réflexions sur l'amylose. In: Arthropathie des dialysés et amylose $\beta 2 \mathrm{M}$. Paris: Gambro, 1987: 57-65.

43 Urena $P$, Zingraff J, Noel L H, Bardin $\mathrm{T}$, Druëke T. Tissue uptake of ${ }^{125} \mathrm{I}-\beta$ microglobulin $\left(\boldsymbol{\beta}_{2}-\mathbf{M}\right)$ in anephric animals in the presence or absence of aluminium intoxication. Nephrol Dial Transpl 1988; 3: 632-6.

44 Alfrey A C, Sedman A, Chan Y L. The compartmentalization and metabolism of aluminium in uremic rats. $\mathcal{F}$ Lab Clin Med 1985; 105: 227-33.

45 Crapper McLachlan D R, Lukiw W J, Kruck T P A. New evidence for an active role of aluminium in Alzheimer's disease. Can f Neurol Sci 1989; 16 : 490-7.

46 Perl D P, Brody A R. Alzheimer's disease: X-ray spectrometric evidence of aluminium accumulation in neurofibrillary tangle-bearing neurons. Science 1980; 208: 297-9.

47 Candy J M, Oakley A E, Klinowski J, et al. Aluminosilicates and senile plaque formation in Alzheimer's disease. Lancet 1986; i: 354-7.

48 Martyn C N, Barker D J P, Osmond C, Harris E C, Edwardson J A, Lacey R F. Geographical relations between Alzheimer's disease and aluminium in drinking water. Lancet 1989; i: 59-62.

49 Yokel R A, Provan S D, Meyer J J, Campbell S R. Aluminium intoxication and the victim of Alzheimer's disease: similarities and differences. Neurotoxicology 1988; 9: 429-42.

50 Candy J, Oakley A E, Gauvreau D, et al. Association of aluminium and silicon with neuropathological changes in the ageing brain. Interdisciplinary Topics in Gerontology 1988; 25: 140-55.

51 Edwardson J A, Candy J M. Aluminium and the pathogenesis of senile plaques in Alzheimer's disease. Down's syndrome and chronic renal dialysis. Annals of Medicine 1989; 21 : 95-7.

52 Vinters $\mathrm{H}$ V, Miller B L, Pardridge W M. Brain amyloid and Alzheimer disease. Ann Intern Med 1988; 109: 41-54. 